\title{
ПСЕВДОНІМ У СИСТЕМІ ОНІМІВ: ЙОГО СТАТУС, ТИПИ Й ФУНКЦІї (аналіз особливостей творення псевдонімів сучасних українських письменників)
}

\author{
ДОМІНІКА ЯНЧУРА \\ Університет імені Адама Міцкевича, Познань - Польща \\ dominikajanczura@interia.eu; ORCID: 0000-0001-5634-7044 \\ PSEUDONIM W STRUKTURZE NAZW WŁASNYCH: \\ JEGO STATUS, TYPY I FUNKCJE \\ (analiza specyfiki tworzenia pseudonimów \\ współczesnych pisarzy ukraińskich) \\ DOMINIKA JANCZURA \\ Uniwersytet imienia Adama Mickiewicza, Poznań — Polska
}

STRESZCZENIE. Artykuł poświęcony jest historii badań nad pseudonimami jako jednym z podtypów nazw własnych. Opisano szeroko stosowaną w ukraińskim językoznawstwie wieloaspektową klasyfikację pseudonimów oraz interpretację ich statusu językowego. Zaproponowano interpretację mechanizmów tworzenia pseudonimów wybranych współczesnych pisarzy ukraińskich oraz ich funkcje w dzisiejszej przestrzeni języka ukraińskiego. Nakreślono zasadnicze tendencje, wyznaczono perspektywę badań.

Słowa kluczowe: nazwa własna, status językowy, pseudonim, ukraiński obszar językowy.

\section{PSEUDONYM IN ONYM SYSTEM: ITS STATUS, TYPES AND FUNCTIONS (peculiarity analysis of pseudonym formation by ukrainian writers)}

\author{
DOMINIKA JANCZURA \\ Adam Mickiewicz University, Poznań — Poland
}

\begin{abstract}
The article focuses on the investigation history of pseudonyms as one of the category, which is singled out among proper names. The multiaspect pseudonym classifications in Ukrainian linguistics and the definition of their linguistic status have been described. The interpretation of the pseudonym formation mechanism by modern Ukrainian writers have been suggested; the functions of pseudonyms in the Ukrainian language space have been analyzed; the correspondent tendencies have been singled out; the research perspectives have been determined.
\end{abstract}

Key words: proper name, linguistic status, pseudonym, Ukrainian language space.

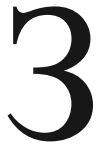

агальновідомо, що пропріальна лексика відіграє важливу роль у житті кожної окремої людини, як і суспільства загалом. Система власних назв постійно привертає увагу дослідників.

Вивчення пропріальної лексики, як відомо, відбувається в межах ономастики. А. Зубко пропонує сучасне визначення цього терміна, порівн.: „Ономастика (від гр. опота - “ім’я, назва") - спеціальна історична дисципліна, що вивчає власні імена, їхнє функціонування в мові і суспільстві, закономірності їх- 
нього утворення, розвитку і постійних перетворень"'. Зазначений учений додає, що „кожен онім - власна назва — містить інформацію про особливості іменованого об'єкта, у якій виникла назва, етнос, котрий створив назву, мову, на якій створена назва і багато іншого"2. Уперше цей термін був запропонований хорватським лінгвістом Т. Маретичем 1886 р., але первісно ономастика вивчала лише антропоніміку ${ }^{3}$.

Безперечно, оніми мають велике значення в пізнанні історії людства. Найбільш важливу роль відіграють у цьому власні назви людей, тобто антропоніми. Усе, що стосується людини, зокрема їі біологічної природи, расового типу тощо, відбилося в предметі вивчення антропоніміки, що є одним з основних розділів ономастики. В антропонімії відображено національну красу та їі своєрідність ${ }^{4}$. Особові імена не пов'язані із зовнішністю людини, хоч колись імена людей виконували функцію оберегів, що, за віруваннями давніх слов'ян, захищали людину від зла 5 .

Антропонімія включає всю множину власних назв окремих людей. Це індивідуальні особові імена з усіма їхніми варіантами та похідними, патронімічні імена (їхня роль у різних лінгвокультурах неоднакова), прізвища, псевдоніми, прізвиська тощо. Особливу увагу ономастів привертають оніми видатних людей, насамперед письменників. Письменники впливають на функціонування державної мови, віддзеркалюють національні особливості мовлення, поширюють кращі його зразки тощо. Вочевидь, серед чинників, що впливають на популярність письменника, його успішність, є творче ім'я. Інколи для більшої атракційності, підвищення ефекту сприйняття творчості письменники використовують псевдоніми. Псевдонім - „вид антропоніма, прибране, вигадане ім'я, що має за мету маскування письменників (або інших авторів певних творів, акторів, художників тощо)" ${ }^{\prime}$. Отже, псевдоніми - засіб вторинної номінації особи. Питання псевдонімів в українському мовознавстві розглядали такі вчені, як М. Лесюк $^{7}$, В. Німчук ${ }^{8}$, Н. Павликівська ${ }^{9}$, П. Чучка ${ }^{10}$. Н. Павликівська, зокрема, пропонує досить чітку дефініцію цього поняття, що відповідає сучасному розвитку ономастики, порівн.: „Псевдонім - різновид антропоніма, прибране (вигадане) особове іменування, яке використовують представники окремих груп суспільства (письменники, публіцисти, композитори, актори, художники, співаки,

1 А. М. Зубко, Українська ономастика: здобутки та проблеми, [в:] Спеціальні історичні дисцинліни: питання теорії та методики, зб. наук. праць, Київ 2007, с. 262.

2 Там само.

3 Там само, с. 264.

4 Там само, с. 270.

5 Там само.

6 I. М. Железняк, Псевдонім, [в:] Українська мова: енџиклопедія, редкол. В. М. Русанівський, О. О. Тараненко та ін., Київ 2000, с. 501.

7 Див.: М. П. Лесюк, Неофічійний антропонімікон УПА, [в:] „Галичина. Науковий і культурно-просвітній краєзнавчий часопис", Івано-Франківськ 2002, № 8, с. 126-139; М.П. Лес юк, Псевда вояків Української Повстанської Aрмії, [в:] Studia Slawistyczne, Nazewnictwo na pograniczach etniczno-językowych, pod redakcją Zofii Abramowicz, Leonardy Dacewicz, Białystok 1999, s. 117-184.

8 Див.: В. В. Німчук, Украӥнська ономастична термінологія, [в:] „Повідомлення Української ономастичної комісії (проект)", Київ 1966, вип. 1, с. 24-43; В.В.Нім чук, Про украӥнську псевдонімію та криптонімію, [в:] „Українська мова”, 2002, № 2, с. 30-58.

9 Див.: Н. М. Павликів ська, Украӥнська псевдонімія XX століття, автореф. дис. ... докт. філол. наук, Київ 2010.

10 Див.: П. П. Чучка, Українські псевдоніми: статус, структура і функиії, [в:] „Наукові записки КДПУ”, Кіровоград 2001, вип. 37, с. 82-83. 
громадсько-політичні діячі, злочинні елементи) поряд зі своїм справжнім іменем та прізвищем або замість них з метою конспірації через причини особистісного, політичного та юридичного характеру"11. Ураховуючи лінгвістичний статус псевдоніма, сферу та тривалість його поширення, Н. Павликівська пропонує інтегральні ознаки останнього ${ }^{12}$. Зазначена дослідниця наголошує, що псевдонім - це назва: 1) вторинна, 2) факультативна, нерегламентована законодавством, 3) здебільшого позначена інформативністю та характеристичністю, 4) залежно від сфери вживання може набувати певних конотацій та виконувати у зв’язку із цим додаткові функції (оцінну, символічну, естетичну та ін.). Серед соціокомунікативних і функціональних ознак псевдоніма вищезгадана дослідниця виокремлює такі: 1) псевдонім - це неофіційна назва особи, яку можна вживати й в офіційних ситуаціях; 2) призначення псевдоніма особливе, оскільки він оберігає таємницю справжнього іменування індивіда; 3) псевдонім виконує езотеричну функцію, що властива тільки йому; 4) уживання псевдоніма пов'язане із суспільною діяльністю носія (письменники, журналісти тощо); 5) псевдоніми можуть бути самоназвами (зокрема літературно-мистецькі) або їх може людині надавати оточення (передусім ідеться про громадсько-політичні псевдо); 6) функції, які виконує псевдонім, зумовлені належністю його до певного класу (напр., літературно-мистецькі псевдоніми можуть стати прецедентними, набувати сталості, тим самим заміняти справжнє ім'я; для інших різновидів характерне вживання протягом конкретного періоду); 7) псевдонім, що стає єдиним іменем людини, утрачає свою специфіку й переходить в інший розряд антропонімії; 8) псевдоніми не є спадкоємними; 9) одна людина може мати один, кілька й багато псевдонімів.

На вибір псевдоніма впливає багато чинників, зокрема національність індивіда, місце проживання, соціальна належність, риси характеру чи фізичні особливості і под. Уважається, що псевдоніми добираються за характерною, найбільш яскравою ознакою конкретної особи. Для літературних псевдонімів мотивом номінації можуть бути тематика творів, жанри, що найбільш характерні для письменника, та ін. Погоджуємось із думкою Н. Щербакової, що псевдоніми сучасних митців виконують не тільки езотеричну функцію, а й “рекламну”, стаючи способом привернення уваги до себе ${ }^{13}$.

Аналізуючи мотиваційну базу псевдонімів, зокрема літературних, учені виокремлюють такі принципи номінації $\left.{ }^{14}: 1\right)$ людина в суспільстві (принцип, що вказує на зв'язок індивіда 3 іншими людьми, дає характеристику за професією чи видом занять, соціальним становищем, етнічно-національною належністю, спорідненістю людей); 2) людина й реалії довкілля (указують на ставлення номінатора до флори й фауни рідного краю, топографічних та географічних об'єктів тощо); 3) номінація за характерними ознаками носія (фізичними, психічними, інтелектуальними); 4) відіменна номінація (модифікація справжнього імені, прізвища чи імені по батькові); 5) принцип латенції (називання, яке навмисне вказує на те, що справжнє ім'я автора приховане).

11 Н. Пав ликі в ська, Псевдоніми як засіб вторинної номінації особи, [в:] „Мовознавчий вісник", зб. наук. праць, 2012, вип. 14-15, с. 135-136.

12 Там само, с. 136.

${ }^{13}$ Н.В.Щер бако ва, Псевдоніми сучасних українських митців в аспекті етнокультури, [в:] „Лінгвістичні дослідження”, зб. наук. праць ХНПУ ім. Г. С. Сковороди, наук. ред. Л. А. Лисиченко, Харків 2011, вип. 32, с. 46.

14 Ди в.: Н. Павл ик і в ька, Псевдоніми як засіб вторинної номінації особи..., с. 138-140. 
На думку М. Торчинського, „псевдонімію можна вважати найменш розробленою у денотатно-номінативному плані, оскільки практично ніхто 3 дослідників не розрізняє додаткових підвидів у їі складі, усупереч розмаїттю таких найменувань у реальному житті"'15. Утім, цей дослідник пропонує розширену систематизацію псевдонімів, а саме: 1) клерикал- (псевдоніми церковних діячів), 2) логос(псевдоніми вчених), 3) міліті- (псевдоніми військових діячів), 4) політик- (псевдоніми політичних діячів), 5) спорт- (псевдоніми спортсменів), 6) віртуал- (псевдоніми користувачів комп'ютером або Інтернетом), 7) оказіонал- (псевдонім, що його використовують у звичайній побутовій ситуації), 8) арт-псевдоніми (псевдоніми діячів мистецтва), що розмежовані на (а) белетристик- (псевдоніми письменників), (б) вокал- (псевдоніми співаків), (в) імажо- (псевдоніми художників, скульпторів), (г) музик- (псевдоніми композиторів, музикантів), (г) публіцистик(псевдоніми теле- й радіожурналістів), (д) сцено- (псевдоніми артистів театру й кіно), (е) фільмо- (псевдоніми творців фільму), (є) цирк- (псевдоніми артистів цирку), (ж) шоу- (псевдоніми артистів розмовного жанру) ${ }^{16}$.

Інший розподіл - за шляхом творення - дає змогу виокремити такі типи $\left.{ }^{17}: 1\right)$ криптоніми (використання літери або літер замість повного імені автора), 2) анаграми (утворені шляхом перестановки літер), 3) аноніми (різновид анаграми; утворені шляхом зворотнього написання літер), 4) апокопа (усічене прізвище), 5) астроніми (складаються із зірочок ***), 6) дульніми (складаються $з$ нулів), 7) складноскорочені (утворюються з фрагментів імені й прізвища), 8) патроніми (утворені від імені батька), 9) апелятиви (звичайне слово, що вживається як псевдонім), 10) геоніми (утворені від географічних назв), 11) хареоніми (використання біблійних або церковних термінів), 12) іноземні слова у функції псевдоніма, 13) іноземні імена або прізвища, перекладені на рідну мову, 14) змішані (подвійні), що складаються зі справжнього й вигаданого прізвища, 15) імена літературних героїв, використані для псевдоніма, 16) "промовисті" (містять оцінку, елемент характеристики).

П. Чучка серед мотивів утворення псевдонімів називає й указівку на бажання уникнути переслідування з боку суспільства, позбутися справжнього прізвища, що не влаштовує автора, спробу “заманіфестувати” через самоназву національне, ідеологічне чи естетичне кредо тощо ${ }^{18}$. Використання псевдонімів викликає в довкіллі певну реакцію, відповідні емоції, асоціації і под. Зважаючи на це, М. Яцемірська пропонує виокремити іронім, зауважуючи, що це ,жартівливий чи іронічний псевдонім"19. Як видається, яскравим репрезентантом цього типу є псевдо Тараса Шевченка - Дармограй, адже, як відомо, поет використовував два псевдо: українськомовні тексти він підписував як Кобзар, а російськомовні - Дармограй, очевидно, наголошуючи цим, що іронізує над собою, оскільки й сам розуміє, що його російськомовні твори не матимуть популярності, успіху ${ }^{20}$.

15 М. Торчи нський, Денотатно-номінативна структура псевдонімії як складник української ономастичної терміносистеми, [в:] „Українське мовознавство”, 2010, № 40, с. 59-61.

16 Там само, с. 58.

17 Див.: В. Е. Федорищев, Способы образования русских и украинских литературных псевдонимов, [в:] Шоста республ. ономастична конф. "Теоретична та історична ономастика", тези доповід. і повід., у 2 томах, Одеса 1990, т. 1, с. 161-163.

18 Див.: П. Чучка, Власне українські особові імена, [в:] „Дивослово”, 2004, № 4, с. 19-22.

19 М. Яци мірська, Сучасний медіатекст, словник-довідник, Львів 2005, с. 47.

20 Див. докладніше: Т. Ко смеда, Ego i Alter Ego в комунікативному просторі щоденникового дискурсу, Дрогобич 2012. 
Як було зазначено, псевдо сучасних митців, зокрема й українських, виконують рекламну функцію. Н. Щербакова зауважує, що „орієнтація на комерційний успіх здебільшого й спричинила поступове відмежування від національного мовного матеріалу на користь інакшості псевдоніма"21. Ця тенденція помітна переважно у співаків, порівн.: Alyosha (Олена Кучер), Джамала (Сусанна Джамаладінова). Тим не менше, на нашу думку, українські письменники як своєрідні “охоронці” народної мови таку тенденцію майже не зреалізовують.

Сучасні письменники активно використовують самоназви, напр.: Ропет Камідян (Петро Миколайович Мідянка), В'ячеслав Григорович Медвідь (Медвєдєв), Богдан-Олег Горобчук (Богдан Дмитрович Горобчук), Лесик Панасюк (Олексій Геннадійович Панасюк), Юрко Винничук (Юрій Павлович Винничук), Галина Пагутяк (Галина Василівна Москалець), Олесь Ульяненко (Олександр Станіславович Ульянов), Анатолій Дністровий (Анатолій Олександрович Астаф’ єв), Любко Дереш (Любомир Андрійович Дереш), Неда Неждана (Надія Леонідівна Мірошниченко), Лесь Подерв'янський (Олександр Сергійович Подерв'янський), Анна Багряна (Ганна Юріївна Багрянцева), Кость Вілійович Москалець (Костянтин Вілійович Москалець).

Як переконує здійснений аналіз, найбільш популярний прийом творення псевдо - уживання зменшено-пестливої форми справжнього імені, порівн.: Юрко Винничук (псевдонім) - Юрій Павлович Винничук (справжнє ім'я); Любко Дереш (псевдонім) - Любомир Андрійович Дереш (справжнє ім'я); Кость Вілійович Москалець (псевдонім) - Костянтин Вілійович Москалець (справжнє ім'я); Лесик Панасюк (псевдонім) - Олексій Геннадійович Панасюк (справжнє ім'я); Лесь Подерв'янський (псевдонім) - Олександр Сергійович Подерв' янський (справжнє ім'я).

Олесь Ульяненко для створення свого псевдо використав не тільки зменшено-пестливу форму справжнього імені, але й модифікацію прізвища шляхом додавання суфікса -енк(о), що є характерним для прізвищ людей української національності, порівн.: Олесь Ульяненко (псевдо) - Олександр Станіславович Ульянов (справжнє повне ім'я та прізвище).

В'ячеслав Григорович Медвєдєв створив псевдонім шляхом зміни прізвища, що був уписаний колись у паспорті його батька воєнкомом, на "українізоване" прізвище, порівн.: В'ячеслав Григорович Медвідь (псевдонім) - В'ячеслав Григорович Медвсдсв (справжні ім'я, по батькові та прізвище). Така тенденція простежується в сучасній Україні - прагнення позбутися російського впливу й у системі антропонімів. Утім, можливо такі трансформації прізвищ не слід відносити до псевдо, а розглядати зазначене явище як прагнення модифікувати колись спотворене прізвище на питоме українське, що відповідає національності людини, відповідним традиціям.

Анна Багряна - псевдонім, що утворений завдяки використанню похідного імені від справжнього та усіченого прізвища (можливо, це свідоме використання прізвища болгарської письменниці Елісавети Багряни), порівн.: Анна Багряна (псевдонім) - Ганна Юріївна Багрянцева (справжнє повне ім'я та прізвище).

Богдан-Олег Горобчук - псевдонім, утворений через використання справжнього й вигаданого імен, порівн.: Богдан-Олег Горобчук (псевдонім) - Богдан Дмитрович Горобчук (справжні ім’я, по батькові та прізвище).

${ }^{21}$ Н. В. Щер баков а, Псевдоніми сучасних украйнських митців в аспекті етнокультуpu..., c. 46. 
Ропет Камідян - псевдонім, утворений шляхом перестановки складів у справжніх імені й прізвищі, порівн.: Ро-пет Ка-мідян (псевдонім) - Пет-ро Миколайович Мідян-ка (справжні ім'я, по батькові та прізвище).

Галина Василівна Москалець як псевдонім використала своє дівоче прізвище Пагутяк, порівн.: Галина Пагутяк (псевдонім) - Галина Василівна Москалець (справжні ім'я, по батькові та прізвище).

Анатолій Дністровий - псевдонім, що утворений від географічної назви ріки Дністер, порівн.: Анатолій Дністровий (псевдонім) - Анатолій Олександрович Астаф'єв (справжні ім'я, по батькові та прізвище).

Неда Неждана - псевдонім, що повністю приховує справжні особові дані, оскільки Неда - це певним чином інтимізоване ім'я, “камерне”, у дитинстві відоме лише близькому оточенню письменниці, а ім'я Неждана засвідчує деяку “містику”, указує на таємницю з'яви на світ, крім того, також омовлює любов українців до евфонії, милозвучності, оскільки багаторазово повторюється сонорний звук, “пом'якшуючи” вимову, порівн.: Неда Неждана (псевдонім) Надія Леонідівна Мірошниченко (справжні ім'я, по батькові та прізвище).

Як бачимо, письменники часто користуються псевдонімами, що в ономастиці прийнято номінувати арт-псевдонімами, або белетристик-псевдонімами. Для цього вони актуалізують усі відомі в ономастиці прийоми творення псевдо. Роблять це з метою реклами своєї особистості, популяризації. Вони інтимізують псевдо, роблять їх більш благозвучними, виразними, експресивними, яскравими, прагнуть, щоб вони викликали позитивні емоції, відповідали українським традиціям, були містичними, загадковими і под. Дослідження механізмів творення псевдонімів дає змогу простежити певну лінгвокреативність українців, оскільки інколи залучається система перерахованих вище прийомів їхнього творення, з'являються й деякі нові тенденції, насамперед пов'язані з усвідомленням своєї національної приналежності.

\section{Список використаної літератури}

Железняк І. М., Псевдонім, [в:] Українська мова, енциклопедія, редкол. В. М. Русанівський, О. О. Тараненко та ін., Київ 2000.

Зубко А. М., Українська ономастика: здобутки та проблеми, [в:] Спеціальні історичні дисципліни: питання теорії та методики, зб. наук. праць, Київ 2007, с. 262-281.

Космеда T., Ego i Alter Ego в комунікативному просторі щоденникового дискурсу, Дрогобич 2012.

Павликівська Н., Псевдоніми як засіб вторинної номіначії особи, [в:] „Мовознавчий вісник", зб. наук. праць, 2012, вип. 14-15, с. 135-141.

Торчинський М., Денотатно-номінативна структура псевдонімії як складник української ономастичної терміносистеми, [в:] ,Українське мовознавство”, 2010, № 40, c. $57-63$.

Федорищев В. Е., Способы образования русских и украинских литературных псевдонимов, [в:] Шоста республ. ономастична конф. „Теоретична та історична ономастика", тези доповід. і повід., у 2 томах, Одеса 1990, т. 1, с. 161-163.

Чучка П., Власне українські особові імена, [в:] „Дивослово”, 2004, № 4, с. 19-22.

Щербакова Н. В., Про сочіальні аспекти псевдонімної номіначії, [в:] „Лінгвістичні дослідження", зб. наук. праць ХНПУ ім. Г. С. Сковороди, наук. ред. Л. А. Лисиченко, Харків 2015, вип. 40, с. 164-170.

Щербакова Н. В., Псевдонім для віртуальної особистості, [в:] „Психолінгвістика”, зб. наук. праць ДВНЗ Переяслав-Хмельн. держ. пед. ун-т ім. Гр. Сковороди, ред. Л. О. Калмикова, Переяслав-Хмельницький 2009, вип. 3, с. 179-183. 
Щербакова Н. В., Псевдоніми сучасних українських митиів в аспекті етнокультури, [в:] „Лінгвістичні дослідження”, зб. наук. праць ХНПУ ім. Г. С. Сковороди, наук. ред. Л. А. Лисиченко, Харків 2011, вип. 32, с. 42-47.

Яцимірська М., Сучасний медіатекст, словник-довідник, Львів 2005.

\section{Spysok vykorystanoi literatury [References]}

Zhelezniak I. M., Psevdonim [Pseudonym], [v:] Ukrainska mova, entsyklopediia, redkol. V. M. Rusanivskyi, O. O. Taranenko ta in., Kyiv 2000.

Zubko A. M., Ukrainska onomastyka: zdobutky ta problemy [Ukrainian Onomastics: Achievements and Problems], [v:] Spetsialni istorychni dystsypliny: pytannia teorii ta metodyky, zb. nauk. prats, Kyiv 2007, c. 262-281.

Kosmeda T., Ego i Alter Ego v komunikatyvnomu prostori shchodennykovoho dyskursu [Ego and Alter Ego of Taras Shevchenko in Communicative Space of Diary Discourse], Drohobych 2012.

Pavlikivska N., Psevdonimy yak zasib vtorynnoi nominatsii osoby [Psevdonym as Means of Secondary Nomination of Person], [v:] „Movoznavchyi visnyk”, zb. nauk. prats, 2012, vyp. $14-15$, s. $135-141$.

Torchynskyi M., Denotatno nominatyvna struktura psevdonimii yak skladnyk ukrainskoi onomastychnoi terminosystemy [Denotative, Nominative Structure of Pseudonims as Component of Ukrainian Onomastic Terminological System], [v:] „Ukrainske movoznavstvo", 2010, № 40, s. 57-63.

Fedorishhev V. E., Sposoby obrazovaniya russkih i ukrainskih literaturnyh psevdonimov [Means of Formation of Russian and Ukrainian Literature Pseudonims], [v:] Shosta respubl. onomastychna konf. „Teoretychna ta istorychna onomastyka”, tezy dopovid. i povid., u 2 tomakh, Odesa 1990, t. 1, s. 161-163.

Chuchka P., Vlasne ukrainski osobovi imena [Ukrainian Proper Names], [v:] „Dyvoslovo”, 2004, № 4, s. 19-22.

Shcherbakova N. V., Pro sotsialni aspekty psevdonimnoi nominatsii [About Social Aspects of Pseudonym Nomination], [v:] „Linhvistychni doslidzhennia”, zb. nauk. prats KhNPU im. H. S. Skovorody, nauk. red. L. A. Lysychenko, Kharkiv 2015, vyp. 40, s. 164-170.

Shcherbakova N. V., Psevdonim dlia virtualnoi osobystosti [Pseudonym for Virtual Personality], [v:] „Psykholinhvistyka”, zb. nauk. prats DVNZ Pereiaslav-Khmeln. derzh. ped. un-t im. Hr. Skovorody, red. L. O. Kalmykova, Pereiaslav Khmelnytskyi 2009, vyp. 3, s. $179-183$.

Shcherbakova N. V., Psevdonimy suchasnykh ukrainskykh myttsiv $v$ aspekti etnokultury [Pseudonyms of Modern Ukrainian Artists Ethno-Culture Aspect], [v:] „Linhvistychni doslidzhennia", zb. nauk. prats KhNPU im. H. S. Skovorody, nauk. red. L. A. Lysychenko, Kharkiv 2011, vyp. 32, s. 42-47.

Yatsymirska M., Suchasnyi mediatekst [Modern Media Text], slovnyk-dovidnyk, Lviv 2005. 